\begin{tabular}{|c|c|c|c|c|} 
Revista Praxis & ISSN: $1657-4915$ & Vol. 12 & $52-62$ & Enero - Diciembre de 2016 \\
\hline
\end{tabular}

\title{
PRONUNCIATION IMPROVEMENT IN EFL YOUNG LEARNERS THROUGH PHONICS INSTRUCTION
}

\author{
MEJORAMIENTO DE LA PRONUNCIACIÓN EN ESTUDIANTES DE EDUCACIÓN \\ PRIMARIA, A TRAVÉS DE LA INSTRUCCIÓN FÓNICA
}

\author{
María Andrea Beltrán-Herrera1', Lilian Lucero Andrade-Chávez², Daniel Felipe Álvarez-Rojas³
}

\begin{abstract}
This article is based on a mixed research, whose objective was the use of Phonics Instruction to improve pronunciation of four sounds $/ \theta /, / \delta /, / / /$ and $/ \mathrm{l}: /$ in young learners in a private school in Bogotá. In this research, the impact of Phonics Instruction was analyzed in the students' pronunciation. To perform this analysis, Phonics Instruction was implemented in five stages based on Lloyd (2007) six types of sections. The participants were 13 students aged 10 to 12 years old from fifth grade; a mixed method was carried out to analyze collected data through the following instruments: 2 tests (pre-post), recordings and artifacts. This analysis was made using randomly 6 chosen students. At first the students did the pre-test with 20 words containing the sounds / $\mathrm{i} / \mathrm{l} / \mathrm{I} / \mathrm{l} / / \theta$ / and / $\mathrm{\partial} /$. In the second phase, the researchers implemented the stages of Phonics Instruction focusing on making visual, auditory, Kinesthetic and tactile. In the third stage, students did the post-test with 40 words containing / $\mathrm{i}: /, / \mathrm{l} /, / \theta$ / and / $\partial$ / sounds, the recordings obtained the pronunciation of students and transcripts of tests; so it could be determined if students improved their pronunciation of sounds with the use of Phonics Instruction. There were also artifacts as evidence of activities did by students. Finally, the results showed that the students had a breakthrough and Phonics Instruction contributed in their pronunciation achieving to identify differences and similarities in word pronunciation based on the minimal pairs.
\end{abstract}

Keywords: Phonics Instruction, EFL pronunciation, young learners, minimal pairs (/ $\theta /, / 0 /, / / /$ and /l:/).

\section{RESUMEN}

Este artículo se basa en una investigación mixta, cuyo objetivo fue el uso de la instrucción fónica para mejorar la pronunciación de los cuatro sonidos / $\theta$ /, / ठ /, / / y / i: / en los jóvenes estudiantes en una escuela privada en Bogotá. En la investigación, se analizó el impacto de la instrucción fónica en la pronunciación de los estudiantes. Para realizar este análisis, la instrucción fónica se llevó a cabo en cinco etapas basadas en Lloyd (2007), en seis secciones. Los participantes fueron 13 estudiantes de edades comprendidas entre 10 y 12 años de quinto grado; un método mixto se llevó a cabo para analizar los datos recogidos

Reception date: Junio 30 de 2016 / Date of acceptance: Agosto 29 de 2016

Typology: Artículo de Investigación Científica y Tecnológica

To quote this article: Beltrán, H. M., Andrade, Ch. L. \& Álvarez, R. D. (2016). Pronunciation improvement in EFL young learners through phonics instruction. Praxis. Vol. 12, 52-62

1. Estudiante, Corporación Universitaria Minuto de Dios, Colombia E-mail: beltranherreram.andrea@gmail.com

2. Estudiante, Corporación Universitaria Minuto de Dios, Colombia E-mail: lilian.andrade064@gmail.com

3. Estudiante, Corporación Universitaria Minuto de Dios, Colombia E-mail: dannyalvarezrojas@gmail.com 
a través de los siguientes instrumentos: 2 pruebas (pre-post), grabaciones y artefactos. Este análisis se realizó utilizando al azar 6 estudiantes. Al principio, los estudiantes hicieron el pre-test con 20 palabras que contenía los sonidos / $\theta$ /, / ठ /, /I / y / i: /. En la segunda fase, los investigadores implementaron las etapas de instrucción fónica centrándose en hacer actividades de movimiento, visuales, auditivas y táctiles. En la tercera etapa, los estudiantes hicieron el post-test con 40 palabras que contenía / $\theta$ /, / ठ/, / / y / : / sonidos; de las grabaciones se obtuvo la pronunciación de los estudiantes y las transcripciones de las pruebas, por lo que se pudo determinar si los estudiantes mejoraron su pronunciación de los sonidos con el uso de la instrucción fónica. También hubo artefactos como evidencia de actividades realizadas por los estudiantes. Por último, los resultados mostraron que los estudiantes tuvieron un gran avance y la instrucción fónica contribuyó en su pronunciación logrando identificar las diferencias y similitudes en la pronunciación de las palabras a partir de los pares mínimos.

Palabras clave: instrucción fónica, pronunciación, estudiantes de educación primaria, pares mínimos.

\section{INTRODUCTION}

$\mathrm{T}$ his research was made with the interest of improving the pronunciation in EFL young learners through Phonics Instruction. This interest was pursued from the limitations that students had in their English classes; which were found through observations, for instance:

- Firstly, students did not have a specific class in which they could practice their English pronunciation. Their environment such as time and the book did not give them great support to practice and improve their pronunciation. Due to this, there was not a moment to teach it and the students had five hours and forty-five minutes per week; the researchers had to adapt to the norms of the school and implement during the classes. According to Mortimer (1997), “encourage students to link words together should be done in the same way as natives do" (p.45). For that reason in the research it was encouraged to the students to start linking sounds in order to be natural and smooth by the time of speaking. Also, Kelly (2001) states that the pronunciation involves the articulation, intonation, stress, vowel, consonants and other parts of the speech that it is not only say and pronounce phonemes.

- Secondly, teacher used a course book titled Smart English 5 (Efuture, 2008) which did not have enough activities to improve their pronunciation. The book was focused on writing, reading and listening skills. Also by the limitations established by the school, the teacher had to cover the units of the book assigned for only a two-month period.

- Thirdly, the Ministry of Education (MEN, 2006) demands for each school grade some standards that have to be fulfilled. However, in fifth grade there are not standards that specify that teachers have to follow certain guidelines to improve and practice the pronunciation in the class (p.20). However, pronunciation is important because it helps students feel comfortable at the moment to speak in public, have a clear and understandable conversation and the communication can be improved with an English person or a person who speaks English as a foreign language (Maniruzzaman, 2008)

Though, Phonics Instruction was implemented in order to contribute in the pronunciation that according to Macdonald (2002), "pronunciation is a key element of the learning of oral skills in a second language" (p.3). of young learners of English as a foreign language of two minimal pairs (/ $\theta /, / \partial /, / \mathrm{I} /$ and $/ \mathrm{I}: /)$ in a private school; the minimal pairs are semantically distinct and which differ from each other by one sound only (Vâlimaa, R. 2005). Otherwise, Levis, J. \& Cortes, $V$ (2008), stage "The sound / $\theta$ / has been the target of much argument in pronunciation teaching. Because it is a distinctively English sound which is shared with few other languages" (p.204); in the research it was used to do the comparison with /ð/ minimal pair. To carry out this research it was important to take into account the five stages based on Lloyd (learning the letter sounds, 
learning letter formation, blending, identifying the sounds in words and tricky words) which imply VAKT because students had to face visual, auditory, kinesthetic and tactile learning styles.

Also, to be aware of the pronunciation state of the students it was necessary to apply a pre-test and finally to know their process after Phonics Instruction (implementation), a post- test was implemented minimal pairs within words phrases and sentences. The information of the tests was collected through an audio-recording.

Another important data was the artifacts where the results of activities done in class were collected in order to have evidence and to analyze the process of the students at the moment of the implementation.

Besides, three studies were important to analyze if the phonics instruction is useful tool in a second language; the first study according to Martínez, C. (2011) found that the phonics instruction improved the EFL children's reading comprehension in a private school in Bogota; however Valbuena, C. (2014) used a program called Tucker signing as a phonics instruction for reading in which students read words or sentences through of the program which it is effective in Spanish speakers and not only speakers; in contrast with Ladkert (2009) he improved pronunciation based on consonants through phonics instruction with students from its semester in an university of Japan.

On the other hand, researchers analyzed how students reacted to the implementation of Phonics Instruction, and in the same way answering the question: How does Phonics Instruction contribute to the English pronunciation of two minimal pairs / $\theta$ / voiceless , /ð/ voiced; /I/ short and /i:/ long in EFL fifth graders from Gimnasio Fray Martin de Porres school during the second semester of 2015 ?

\section{METHODOLOGY}

In this project, mixed research method was used with the purpose to analyze the impact of Phonics Instruction in the pronunciation of the minimal pairs $/ \theta /, / \partial /, / \mathrm{i} / /$ and $/ \mathrm{I} /$ in young learners of English as foreign language, the contribution in their learning process and if teaching phonics to these students was effective in their pronunciation. It was done through tests (pre and post), audio-recordings and artifacts; the pre-test and audio-recording helped the researchers to observe, analyze and identify the difficulties at the moment of pronouncing the minimal pairs $/ \theta$ / voiceless, /ð/ voiced; /I/ short and /I:/ long. Also the Phonics Instruction lessons were planned to be implemented with the participants. Likewise, the artifacts could register each aspect of what happened at the moment of the implementation.

The participants of the research were 13 students from 10 to 12 years old from grade fifth and they are considered young learners because according to Nunan (2011) the young learners is around 3 years of age to 15, and randomly 6 students were chosen to do the pre-test and post-test; but the lesson or the implementation of phases were taught to all of the students. It is important to know and according to Cameron (2001) children have the ability to learn a second language better than adults, Thompson (w.d) states they learn easily because they have a part of the brain called "Deep motor area" where children learn in an intuitive way. Also Crosse (2007) states that children can learn an additional language like the first language such as: songs listening the parents in daily events.

Moreover, based on the experience, primary school is one of the most important stage during the learning process of the students because they start to develop the comfortable intelligibility. 
According to Kenworthy (1987), comfortable intelligibility or intelligibility "is to be understood by others by the listener in a given time." (p.145). For that reason, it has been decided to explore and improve this essential and basic step of English pronunciation as a whole.

\section{Research methodology}

The research was centered in collaborative action research Burns (1999) because the researchers had a cooperative work, as each of them had a task at the moment of implementing the research with the specific instruments (tests, audio-recording and artifacts) also, "AR involves taking a self-reflective, critical, and systematic approach to explore your own teaching contexts" (Burns, 2010 p.2); the aim basically was to teach, record and observe what was happening in detail during the class and stages stated by Lloyd (2007) (learning the letter sounds, learning letter formation, reading (blending), identifying the sounds in words and tricky words) in order to identify weaknesses and strengths in students during and after the implementation; so each researcher was in charge of instructing or teaching the pronunciation of the those minimal pairs, recording the students' pronunciation, observing and recollecting the artifacts.

Hence, according to Kemmis and McTaggart cited by Burns (1999) the action research is defined as a dynamic and complementary process and it consists in four steps: planning (develop a plan to improve the problem), action (act to implement the plan) observation (observe what happens in the action) and reflection (reflect about the facts). Hence in this and according to research, this process was set up in the following way:

- Planning: pronunciation was taught using Phonics Instruction because it was proved that students made mistakes pronouncing some words, and the main goal was to plan activities which were appropriate and attractive for students.

- Action: Phonics Instruction stage activities were implemented and observed with the objective of proving if students were effectively answering those activities.

- Observation: researchers observed what happened at the moment of teaching the minimal pairs through Phonics Instruction. (If they learned, if it was effective, if students improved their pronunciation of the specific minimal pairs $/ \theta /, / \delta /, / \mathrm{i} /$ and $/ \mathrm{I} /$ ) and analyze if the phonics instruction contributed in their EFL pronunciation.

- Reflection: the learning process of students was analyzed in terms of the pronunciation using Phonics Instruction.

\section{RESULTS AND DISCUSSION}

The process of analyzing resulted from transcriptions of the tests (pre and post) which were made by the researchers based on data recording of the pre-test and post-test with the words used. The answers in the pre-test showed that those students got 5 right answers out of 20 . However, in contrast with the post-test students showed relevant improvement as they got 23 right answers out of 40 .

The following charts show how is students' pronunciation of those minimal pairs in the pre-test and post-test, taking into account the words that are in bold had a proper pronunciation. Also, researchers selected the most representative words according to the syllabus that the school implemented for that grade, and the students were learning following the minimal pairs that the research chose; for each test 6 students were chosen randomly which were selected by codenumber from the list. 


\section{Chart 1.}

Transcription of the pre-test audio-recording with the minimal pair /// and /i:/

\begin{tabular}{|c|c|c|c|c|c|c|c|c|c|c|}
\hline \multirow{2}{*}{$\begin{array}{c}\# \\
\text { Ss }\end{array}$} & \multicolumn{10}{|c|}{ Minimals pairs /I/ and /i:/ } \\
\hline & Sea & Beach & Ice cream & Heat & Sunscreen & Winter & Hail & Wind & Lightning & Rain \\
\hline 1 & SI & bizz & eiscri:m & hit & siscrem & wainter & jarl & waint & wamnti & $/$ rein/ \\
\hline 2 & sia & bish & eiscri:m & hit & sonscri:m & /'wintər/ & jeil & /wind/ & nainti:n & /rein/ \\
\hline 3 & SI & bish & ais cre & it & sonscrim & /'wintər/ & jeil & /wind/ & laifnain & rain \\
\hline 4 & SI & bi:sh & aiscri:m & hit & sonscri:m & wainter & jeIl & wint & Laifnın & $/$ rein/ \\
\hline 5 & SI & bish & aiscri:m & hit & suscrim & witer & jai & win & Liftin & rain \\
\hline 6 & sei & bish & Is crim & heat & sunscrim & /'wintər/ & jarl & wint & Laiftın & rain \\
\hline \multicolumn{11}{|c|}{ Correct Pronunciation of the Minimal Pairs /I/ and /i:/ } \\
\hline & Sea & Beach & Ice cream & Heat & Sunscreen & Winter & Hail & Wind & Lightning & Rain \\
\hline & /si:/ & /bi:t $\int /$ & /ais kri:m/ & /hi:t/ & /sən'skri:n/ & /'wintər/ & /heil/ & /wind/ & /'laitnin/ & /rein/ \\
\hline
\end{tabular}

Source: own elaboration

\section{Chart 2.}

Transcription of the pre-test audio-recording with the minimal pair / $\theta$ / and / $\partial$ /

\begin{tabular}{|c|c|c|c|c|c|c|c|c|c|c|}
\hline \multirow{2}{*}{$\# \mathrm{~S}$} & \multicolumn{10}{|c|}{ Minimal Pairs /ð/ and / $\theta /$} \\
\hline & Month & Theater & Birthday & Thursday & Thanksgiving & Weather & Breathe & Gather & Scathe & Father \\
\hline 1 & $/ \mathbf{m} \Delta \mathbf{n} \theta /$ & 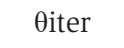 & berdei & tursdai & tinksgiving & weiter & braint & weter & skert & /'faðər/ \\
\hline 2 & $/ \mathbf{m} \Delta \mathbf{n} \theta /$ & $\theta i t e r$ & birdei & $\theta$ orsdei & tinksgiving & weiter & /brið/ & geiter & /skeið/ & /'faðər/ \\
\hline 3 & $/ \mathbf{m} \Delta \mathbf{n} \boldsymbol{\theta} /$ & tiarter & birdai & tursdai & tansgiving & witer & bri $\theta$ & water & iskei & /'faðər/ \\
\hline 4 & $/ \mathbf{m} \mathbf{n} \mathbf{n} \theta /$ & Өiter & biordei & tursdai & tansgiving & weter & breit & geiter & /skeið/ & /'faðər/ \\
\hline 5 & mon & teiter & Birdi & tursdei & tansgiving & witer & bearti & gater & /skeið/ & /'faðər/ \\
\hline 6 & $/ \mathbf{m} \Delta \mathbf{n} \theta /$ & teiter & birӨdei & tursdei & tansgiving & witer & breat & gaðer & escat & /'faðər/ \\
\hline \multicolumn{11}{|c|}{ Correct Pronunciation of the Minimal Pairs $/ ð /$ and $/ \theta /$} \\
\hline & Month & Theater & Birthday & Thursday & Thanksgiving & Weather & Breathe & Gather & Scathe & Father \\
\hline & $/ \mathrm{m} \wedge \mathrm{n} \theta /$ & /'Oiətər/ & /'b3r $\theta$, deI/ & /' $\theta 3 \mathrm{rz}, \mathrm{deI} /$ & /, $\theta æ y k s '$ givin/ & /'wعðər/ & /brið/ & /'gæðər/ & /skeið/ & /'faðər/ \\
\hline
\end{tabular}

Source: own elaboration

In the pre-test five words were chosen for each minimal pair with a total of 20 words which had an image each sound, students could understand the meaning of each word. First, students pronounced the /I/ and /i:/ minimal pairs words and second the $/ \partial /$ and $/ \theta /$ minimal pairs words. As a result, student number 2 got the most correct answers with a score of $(7 / 20)$ and student number 5 got the least correct answers with a score of $(2 / 20)$, the problem of the pronunciation those students was evidenced and identified, thus Phonics Instruction can be logically implemented by the researchers to improve their pronunciation specially with those minimal pairs. 


\section{Chart 3.}

Transcription of the post-test audio-recording with the minimal pair /I/

\begin{tabular}{|c|c|c|c|c|c|c|c|c|c|c|}
\hline \multirow{2}{*}{$\begin{array}{c}\# \\
\text { Ss }\end{array}$} & \multicolumn{10}{|c|}{ Words with /I/ sound } \\
\hline & Winter & Hail & Wind & Lightning & Rain & Fish & Hill & Gift & ice & Mittens \\
\hline 1 & /'wintor/ & Ail & /wind/ & linting & rain & $/ \mathrm{fI}_{\mathrm{I}} \mathrm{J} /$ & eal & gif & if & /'mitənz/ \\
\hline 2 & witer & Jail & wint & ligting & rain & $/ \mathrm{fII}_{\mathrm{I}} /$ & jail & witht & ice & mittes \\
\hline 3 & /'wintər/ & /heil/ & /wind/ & /'lait nin/ & /rein/ & $/ \mathbf{f I}_{\mathbf{I}} \mathbf{s} /$ & /hil/ & /gift/ & /ais/ & /'mitənz/ \\
\hline 4 & /'wintər/ & jail & /wind/ & $\operatorname{lin} \theta$ it & rain & $/ \mathrm{fI}_{\mathrm{I}} \mathrm{f} /$ & /hil/ & gif & if & mit \\
\hline 5 & /'wintor/ & /heil/ & /wind/ & /'laitnıy/ & /rein/ & $/ \mathbf{f}_{\mathbf{I}} \mathbf{f} /$ & /hıl/ & /gift/ & /ais/ & /'mitonz/ \\
\hline 6 & /'wintər/ & /heil/ & /wind/ & /'lait nait/ & /rein/ & $/ \mathrm{fII}_{\mathrm{I}} /$ & jail & /gIft/ & /ais/ & /'mitənz/ \\
\hline \multicolumn{11}{|c|}{ Correct Pronunciation of the Words with /I/ sound } \\
\hline & Winter & Hail & Wind & Lightning & Rain & Fish & Hill & Gift & ice & Mittens \\
\hline & /'wintər/ & /heil/ & /wind/ & /'laitnin/ & /rein/ & $/ \mathrm{fr}_{\mathrm{I}} /$ & /hil/ & /gift/ & /ais/ & /'mitənz/ \\
\hline
\end{tabular}

Source: own elaboration

\section{Chart 4.}

Transcription of the post-test audio-recording with the minimal pair /i:/

\begin{tabular}{|c|c|c|c|c|c|c|c|c|c|c|}
\hline \multirow{2}{*}{ \# Ss } & \multicolumn{10}{|c|}{ Words with /i:/ sound } \\
\hline & Sea & Beach & Ice Cream & Heat & Sunscreen & Tree & Field & Bee & Leaf & Easter \\
\hline 1 & /si:/ & /bi:tg/ & crem & hat & sunscreat & /tri:/ & filt & /bi:/ & /li:f/ & eaters \\
\hline 2 & /si:/ & /bi:tg/ & /aIs/ /kri:m/ & it & sunscreem & /tri:/ & field & /bi:/ & lift & easter \\
\hline 3 & /si:/ & /bi:ty/ & /ais/ /kri:m/ & /hi:t/ & /sən'skri:n/ & /tri:/ & /fi:ld/ & /bi:/ & /li:f/ & /'istor/ \\
\hline 4 & Sis & Bish & /ais/ cream & hey at & sum em & /tri:/ & fil & /bi:/ & lef & earts \\
\hline 5 & /si:/ & /bi:ty/ & /aIs/ /kri:m/ & Het & suns'krin & /tri:/ & /fi:ld/ & /bi:/ & /li:f/ & /'istər/ \\
\hline 6 & /si:/ & /bi:tg/ & /aIs/ /kri:m/ & /hi:t/ & suns 'krin & /tri:/ & /fi:ld/ & /bi:/ & /li:f/ & eister \\
\hline \multicolumn{11}{|c|}{ Correct Pronunciation of the Words with /i:/ or /i/ sound } \\
\hline & Sea & Beach & Ice Cream & Heat & Sunscreen & Tree & Field & Bee & Leaf & Easter \\
\hline & /si:/ & /bi:ty/ & /ais/ /kri:m/ & /hi:t/ & /sən'skri:n/ & /tri:/ & /fi:ld/ & /bi:/ & /li:f/ & /'i:stər/ \\
\hline
\end{tabular}

Source: own elaboration 


\section{Chart 5.}

Transcription of the post-test audio-recording with the minimal pair / $ठ /$

\begin{tabular}{|c|c|c|c|c|c|c|c|c|c|c|}
\hline \multirow{2}{*}{ \# Ss } & \multicolumn{10}{|c|}{ Words with /ð/ sound } \\
\hline & Weather & Breathe & Gather & Clothes & Father & Bathe & Mother & Leather & They & There \\
\hline 1 & eater & breadh & greater & cloders & /'faðər/ & bears & /'m^ðәr/ & lathern & tey & ter \\
\hline 2 & wiether & brede & geidter & clodhes & /'faðər/ & beiter & /'mıðәr/ & leather & /ðеı/ & their \\
\hline 3 & hiter & brid & geiter & /kloøðz/ & /'faðər/ & bat & /'mıðər/ & leiter & /ðё/ & /ðеәr/ \\
\hline 4 & wird & brit & gaider & cloudis & /'faðər/ & beidi & /'mıðər/ & leidir & /ðеі/ & de:ar \\
\hline 5 & werer & briti & /'gæðər/ & /kloogez/ & /'faðər/ & baðI & /'mıðər/ & /'lєðər/ & hey & /ðeər/ \\
\hline 6 & /'wعðər/ & /bred/ & grerer & /klov日ez/ & /'faðər/ & bat & /'mıðər/ & /'letər/ & /ðеı/ & /ðeər/ \\
\hline \multicolumn{11}{|c|}{ Correct Pronunciation of the Words with /ð/ sound } \\
\hline & Weather & Breathe & Gather & Clothes & Father & Bathe & Mother & Leather & They & There \\
\hline & /'wعðər/ & /brið/ & /'gæðər/ & /klovðz/ & /'faðər/ & /beið/ & /'m^ðər/ & /'leðər/ & /ðеІ/ & /ðeər/ \\
\hline
\end{tabular}

Source: own elaboration

\section{Chart 6.}

Transcription of the post-test audio-recording with the minimal pair / $\theta$ /

\begin{tabular}{|c|c|c|c|c|c|c|c|c|c|c|}
\hline \multirow{2}{*}{$\begin{array}{c}\# \\
\text { Ss }\end{array}$} & \multicolumn{10}{|c|}{ Words with $/ \theta /$ sound } \\
\hline & Month & Theater & Birthday & Thursday & Thanksgiving & Breath & Bathtub & Booth & Thanks & Thunder \\
\hline 1 & $/ \mathrm{mun} \theta /$ & tear ter & birtday & tursday & tanksgi:bing & bearth & bathub & bu:ts & tenks & tunder \\
\hline 2 & $/ \mathrm{mun} \theta /$ & tier & bider & tuersday & tanskgibing & bread & bathtub & bouts & tenks & tunder \\
\hline 3 & $/ \mathrm{mun} \theta /$ & /'日iətər/ & /'b3ro,deI/ & /'O3rz,dei/ & 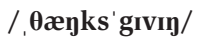 & breith & battumb & but & tanks & tınder \\
\hline 4 & $/ \mathbf{m}_{\Lambda} \mathbf{n} \theta$ & dear & birday & tursday & dankstivint & breat & batshtub & but & $\operatorname{tank}$ & tunder \\
\hline 5 & $/ \mathbf{m} \mathbf{s} n \theta /$ & tirer & birday & Tзrz, deI & tanks'givin & brið & batu $\theta$ & $/$ but/ & /өæりks/ & /'oundor/ \\
\hline 6 & $/ \mathrm{m} \boldsymbol{n} \mathbf{n} \theta /$ & /ө3rd/ & b3r, deI & 'tjuz, deI & /,日ayks'givın/ & bred & ba $\theta u b$ & bo $\theta$ & $\theta$ anks & /'oundor/ \\
\hline \multicolumn{11}{|c|}{ Correct Pronunciation of the Words with $/ \theta /$ sound } \\
\hline & Month & Theater & Birthday & Thursday & Thanksgiving & Breath & Bathtub & Booth & Thanks & Thunder \\
\hline & $/ \mathrm{m} \wedge \mathrm{n} \theta /$ & /'Oiətər/ & /'bзr $\theta$, deI/ & 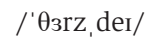 & /, $\theta æ y k s ' g i v ı y /$ & /bre $\theta /$ & 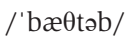 & /bue/ & /өænks/ & /' $\theta \Lambda$ ndər/ \\
\hline
\end{tabular}

Source: own elaboration

The previous four charts corresponding to the post-test, show that each chart is according to one minimal pair, the first minimal pair /I/ used the same five words of the pre-test and added five more (fish, hill, gift, ice and mittens), the second minimal pair /i:/ used five words of the pre-test and added five more (tree, field, bee, leaf and Easter), the third minimal pair /ð/ used four words of the pre-test and added six more (clothes, bathe, mother, leather, they and there) and the last minimal pair $/ \theta /$ used five words of the pre-test and added five more (breath, bathtub, booth, thanks and thunder), with a total of 40 words. Furthermore, student number 3 
got the most answers with a score of $30 / 40$ and the least correct answers were of the students' number 2 and 4 with a score of 10/40. Although the percentage was of $5 \%$, it is an important to highlight that in the post-test the vocabulary was longer and more complex than in the pre-test. Also, another process of collection was based on two categories; the category number 1 /I/ vs /i:/ compared the tests (pre and post) of each student chosen randomly in which described the difficulties, improvements and how each student advanced in his/her pronunciation; and the category number $2 / \theta /$ vs $/ ð /$, same as category one had a comparison with the minimal pairs in each test.

Chart 7.

Category one ///vs/i:/: comparison between pre and post- test of the student number three of the minimal pairs /I/ vs /i:/

\begin{tabular}{|c|c|}
\hline \multicolumn{2}{|c|}{ Category One /I/ vs /i:/ } \\
\hline \multicolumn{2}{|c|}{ Student three } \\
\hline Pre-Test & Post-Test \\
\hline $\begin{array}{l}\text { Reviewing the chart Student Three he was not able } \\
\text { to } \\
\text { pronounce correctly any of the words with the } \\
\text { sound } \\
\text { /i./ }\end{array}$ & $\begin{array}{c}\text { In contrast with the pre-test the student could } \\
\text { identify } 10 \text { out } 10 \text { words that involved the sound } \\
\text { /i:/. Showing an improvement of the } 50 \% \text { taking } \\
\text { into account that a } 100 \% \text { of improvement meant to } \\
\text { answer the } 10 \text { words } \\
\text { correctly. }\end{array}$ \\
\hline $\begin{array}{l}\text { In contrast, it was able to identify two out of the } 10 \\
\text { words with the sound /I/. }\end{array}$ & $\begin{array}{l}\text { And he was able to identify } 10 \text { words out of } 10 \\
\text { with the sound /I/. This meant that it improved a } \\
100 \% \text {. Taking into account that a } 100 \% \text { of improve- } \\
\text { ment meant to answer the } 10 \text { words correctly. }\end{array}$ \\
\hline $\begin{array}{l}\text { In the Pre-Test is possible to observe that the } \\
\text { student } \\
\text { was able to recognize } 20 \% \text { of the words without } \\
\text { Phonics Instruction activities. Bearing in mind } \\
\text { that he was able to pronounce } 5 \text { words out of } 10 \text {. } \\
\text { In which there was none distinction between the } \\
\text { sounds or any kind of distribution. }\end{array}$ & $\begin{array}{c}\text { That meant that Student Three through Phonics } \\
\text { Instruction activities was able to improve a } 100 \% \\
\text { on the pronunciation of the two minimal pairs /i/ } \\
\text { vs /I:/. }\end{array}$ \\
\hline
\end{tabular}

Source: own elaboration

That student had a high percentage in the improvement in his pronunciation; so Phonics Instruction contributed in his pronunciation with the minimal pairs /I/ and /i:/. Besides, in the research it was possible to determine and analyze from the records collected that the implementation of Phonics Instruction activities along with Visual-AuditoryKinesthetic-Tactile (VAKT) Approach, was meaningful for the vast majority of the students. Some of them were able to pass from 0 correct answers to 7 to 10 correct answers. 


\section{Chart 8.}

Category Two / $\theta / v s / ð /:$ comparison between pre and post- test of the student number three of the minimal pairs / $\theta / v s / \delta /$ Source: own elaboration

\begin{tabular}{|c|c|}
\hline \multicolumn{2}{|c|}{ Category Two / $\theta /$ vs /ð/ } \\
\hline \multicolumn{2}{|c|}{ Student three } \\
\hline Pre-Test & Post-Test \\
\hline $\begin{array}{c}\text { By analyzing the results from Student Three, } \\
\text { during the pre-test the student was able to pro- } \\
\text { nounce correct one of five words that included the } \\
\text { sound } / \theta / \text {. }\end{array}$ & $\begin{array}{l}\text { In comparison with the pre-test the student could } \\
\text { pronounce } 5 \text { words from ten showing a great un- } \\
\text { derstanding and improvement of the } / \theta / \text { sound. }\end{array}$ \\
\hline $\begin{array}{l}\text { In addition, the student was able to identify one } \\
\text { out of } \\
\text { five the words with the sound /ð/ }\end{array}$ & $\begin{array}{c}\text { Regarding the sound /ð/, student as it did before } \\
\text { was able to improve from } 1 \text { to } 5 \text { words correctly } \\
\text { pronounced. }\end{array}$ \\
\hline $\begin{array}{l}\text { During the pre-test was able to explore the } \\
\text { previous } \\
\text { knowledge of the students referring to the pronun- } \\
\text { ciation of the minimal pair } / \theta / \text { vs } / ð / \text { however, as } \\
\text { the student had a lack of pronunciation training } \\
\text { was great to know that in somehow he was able } \\
\text { to produce the correct sound in one of } 5 \text { words per } \\
\text { sound. }\end{array}$ & $\begin{array}{l}\text { Once the data collected from the post-test was } \\
\text { coded and analyzed. It was able to determine and } \\
\text { analyze that phonics instruction activities aimed } \\
\text { with the improvement of the pronunciation skill } \\
\text { was useful and let students identify better the } \\
\text { sounds and words, not only isolated but also in } \\
\text { brief and simple conversations. }\end{array}$ \\
\hline
\end{tabular}

In this category, student three had better results pronouncing the sound $/ \theta /$ than the sound $/ \partial /$ and although he had difficulties with the sound /ð/; it was not relevant with his improvement in the pronunciation. Besides, it is important to highlight that the vast majority of the students had a significant improvement based on the two minimal pairs, / $\theta /$, /ð/, /i/ and /I/.

On the other hand, the Lloyd (2007) stages were implemented showing how the process of each stage had place in the research taking into account the tests (pre and post), audio-recording and artifacts instruments used to recollect the information, for instance:

Learning the letter sounds. The use of repetition was a good strategy for students to learn, memorize words and the pronunciation of the specific minimal pairs. For example, a researcher pronounced the sound $/ \theta$ / and students imitated and repeated several times, then the researcher said a word (birthday) and she showed an image related immersed with the word; finally students repeated the word. Also, students had the opportunity to pronounce individually and they corrected themselves and their classmates.

Learning letter formation students liked the activities because they felt like in pre-school decorating the minimal pairs and pronouncing the words; thus they were able to understand better the instructions.

Reading (blending) it was easy for the student to blend sounds like /si:/ but they had trouble with words like mittens in which they focused on the principal sound $/ \mathrm{I} /$, but at the same time they had extra sound /t/, /s/ and /m/. Here students already knew the sounds, because they are similar to the Spanish; they got easily used to them.

Some activities implemented with the students were gap fillings, in order to show them the blending of sound in words with one or more syllables. They had words like, Ice Cream in which they have two sounds /I/ and /i:/ in the same word. 
Identifying the sounds in words students identified of each minimal in a text, they had to underline the words according to the sound.

Tricky words the participants of the research learned new words which contained those minimal pairs, although some were difficult for them (mittens, scathe, bathtub, lightning), through the repetition they had a proper pronunciation. Besides a group of words were used for each minimal pair, then they could recognize and differentiate the minimal pairs.

Consequently, it showed a breakthrough in the EFL learning process of students, specifically in their pronunciation with those minimal pairs; Lloyd (2007) stages were very useful for that process, because the researcher followed each phase in different lessons, despite students were exposed to only few sessions of phonics instruction. They only focused their pronunciation in four minimal pairs. Besides they could differentiate those minimal pairs, although the post-test might have been more complex than the post-test.

As well, during the development of the research some limitations were found, such as:

- First, the book was not an appropriate resource for students in order to encourage their pronunciation considering that the activities proposed on Smart English 5 were not enough to contribute in a balanced learning process of a foreign language.

- Second, the space was not suitable because it was narrow and it was limited for students because they could not move. It was uncomfortable for them to get in bigger groups. They were used to work maximum in pairs.

- Third, as they had three teachers in less than two months they could not have a proper process since the beginning of the Academic Year, because every teacher has its own methodology and with every change the students felt the need to readapt their behavior depending on the new teacher so for them it was complicated and uncomfortable.

Despite these facts, the objective was achieved and the researchers could analyze if the Phonics
Instruction contributed in the pronunciation of the four minimal pairs in young learners even though students didn't have a high level in their pronunciation and these limitations were presented.

After the implementation students were able to acquire a better pronunciation and they were also able to start distinguishing better the sounds in simple phrases or conversations. Also, activities that involved VAKT (Visual-AuditoryKinesthetic-Tactile) approach were outstanding, in order to tackle most of the learning styles in class. However, the effectiveness of Phonics Instruction is highly related to the steps followed at the time of the instruction, and the time dedicated to the sessions of implementation done.

\section{CONCLUSION}

So, it can be concluded that the Phonics Instruction contributes to students' pronunciation achieving to identify several differences and similarities in word pronunciation based on minimal pairs; and supporting their rehearsal process in speaking in terms of: reading words, sentences, gaps filling and even spelling.

Thus, Phonics Instruction can be considered as a great tool not only to learn reading and writing; but also to improve pronunciation in EFL students, taking into account Lloyd (2007) stages and following the whole process. Therefore, students can improve their pronunciation skills in a dynamic and fun way, and most importantly students feel in a comfortable and enjoyable environment to learn and improve their skills. For this it was important the use of VisualAuditory-Kinesthetic-Tactile approach (VAKT) because students needed to learn from different kinds of inputs like visual, tactile, and auditory by relating the activities done.

Besides this, it evidences that activities used in the implementation of Phonics Instruction were enjoyable and comprehensible, because with the process of passing the finger over the sound, students did an association with the pronunciation and the form of the symbols. Also, with several repetitions of hearing words they could 
remember and achieve the purpose that was improving the pronunciation of the minimal pairs /I/ /i:/ and /ð/ / $\theta /$.

Therefore, the use of Phonics Instruction was effective to contribute the pronunciation in the minimal pairs /I/ /i:/ and /ð/ / $\theta /$, but if it is used with more sessions of implementation the students can have a better pronunciation, which can help the students learn English easier. They can enjoy learning it and probably they can have fluency and self-confidence at the moment of developing the four skills (listening, speaking, writing and reading).

Based on the results given by the charts from the transcription it is possible to conclude that Phonics Instructions is useful because the improvement shown by the students was significant and the average of the improvement was more than $50 \%$.

Finally, for other researchers this research can be useful to know the improvement in the pronunciation or difficulties that students can have when pronouncing, to know proper methods to use the stages with Phonics Instruction and the best way to use them in different populations; and improve a different skill. The minimal pairs are also a tool for the learning process of the students, as they can differentiate and pronounce not familiar sounds. We have to consider that Phonics Instruction is not only for native speakers, it could be implemented in EFL students, and it can help to improve anyone skill following step by step of Phonics Instruction.

\section{REFERENCES}

Burns, A. (1999). Collaborative action research for English language teachers. Cambridge University press

Burns, A. (2010). Doing action research in English language teaching. New York: routledge

Cameron, L. (2001). Teaching languages to young learners. UK: Cambridge University press p. 13
Crosse, K. (2007). Introducing English as an additional language to young children. SAGE p. 7

Efuture, E. F. (2008). Smart English 5. (Efuture ed.). Seoul

Kelly, G. K. (2001). How to teach pronunciation. (Second impression ed.). Edinburgh gate: Pearson education limited.

Kenworthy, J. (1987). Teaching English pronunciation, Longman handbooks for teachers. p.13

Levis, J. \& Cortes, V. (2008). Minimal pairs in spoken corpora: implications for pronunciation assessment and teaching. p. 204

Lloyd, S. (2007). The phonics handbook. Jolly learning ltd

Macdonald, S. (2002). Pronunciation - views and practices of reluctant teachers. p. 3

Martínez, A. (2011). Explicit and Differentiated Phonics Instruction As A Tool ToLiteracy Skills For Children Learning English As A Foreign Language.

Ministerio de educación nacional, (2006). Formar en lenguas extranjeras: ingles jel reto!

Maniruzzaman, M. (2008). Teaching EFL pronunciation: why, what and how? (1st ed.). norderstedt germany: grin verlag.

Mortimer, C. (1997). Intensive practice for intermediate and more advanced students. p 45

Nunan, n. .d. (2011). Teaching English to young learners. (1st ed.). retrieved 30 January, 2016, from https://books. google.com.co/books?hl = es\&lr $=\& i d=d$ ncn_qmwevwc \&oi $=$ fnd $\&$ pg $=$ pt $10 \& d-$ $\mathrm{q}=$ nunan,$+\mathrm{d}+(2011)+$ teaching + english + to + young + learners. + p. +5 \&ots $=$ sihkg0 0 w 7 o\&sig $=1$ gzfddmiei0e-iatndfbbsvguri $\# \mathrm{v}=$ onepage $\& \mathrm{q} \& \mathrm{f}=$ false

Thompson, P (w.d) recovered 30th march 2015 from: http://www.ehowenespanol.com/aprendizaje-segundo-idioma-ninos-pequenos-vs adultos-sobre_18383

Valbuena, A. (2014). Tucker Signing As A Phonics Instruction Tool To Develop Phonemic Awareness In Children.Gist $\mathrm{N}^{\circ}$ 8, $71-80$

Vâlimaa, R,(2005). Cognitive phonology in construction grammar. Berlin-New York: Mouton de Gruyter p. 61. 